\title{
Inferior turbinate hypertrophy presenting as bilateral nasal masses in a paediatric patient
}

\author{
Nicholas Armando Rossi 두, Megan L Swonke, Shiva Daram
}

Otolaryngology, University of Texas Medical Branch at Galveston, Galveston, Texas, USA

\section{Correspondence to} Dr Nicholas Armando Rossi; nicholas.armando.rossi@gmail. com

Accepted 30 May 2021

\section{DESCRIPTION}

A 4-year-old boy presented with a lifelong history of nasal obstruction, mouth breathing and snoring. His parents denied any associated rhinorrhoea, sneezing, facial pain, facial swelling, epistaxis, epiphora or sinus infections. Skin prick testing was negative for all environmental allergens. On physical examination, the bilateral nares were completely occluded by smooth, compressible masses that prevented complete examination of the nasal cavities (figure 1 ). The masses did not change in size when either of the internal jugular veins were compressed. CT scan of the sinuses without contrast showed bilateral soft tissue densities obliterating the nasal cavities, extending from the nasal vestibule to the posterior nasopharynx. The masses obstructed the paranasal sinus outflow tracts and bilateral Hasner's valves. All the pneumatised ethmoid, maxillary and sphenoid sinuses demonstrated significant mucosal thickening (figure 2). There was no bony erosion of the skull base, lamina papyracea or bony septum, and no bony expansion of the sinuses or nasal bones was seen.

The final diagnosis was severe bilateral inferior turbinate hypertrophy completely filling the nasal cavities. Initially, aggressive medical management was attempted with a regimen of topical nasal steroid spray, nasal saline spray, oral steroid taper, oral antihistamine and a 3 -week course of oral azithromycin. However, delivery of topical medications to the patient's nasal cavity proved difficult due to significant obstruction and persistent dripping of medication out of the nose, and no clinical improvement was seen. Due to the severity of both nasal obstructive symptoms and severe reactive

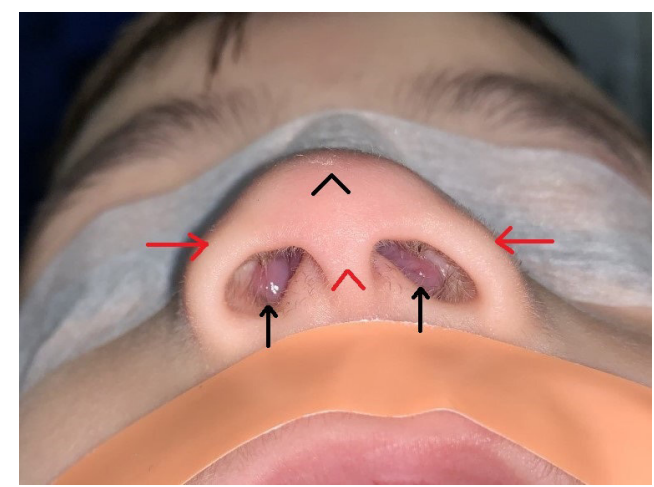

Figure 1 Gross appearance of nasal masses. Basal view of the patient's nose demonstrating bilateral pink soft tissue masses filling the caudal nasal cavity. (Black arrows=nasal masses, black arrowhead=nasal tip, red arrows=nasal ala and red arrowhead=columella.)

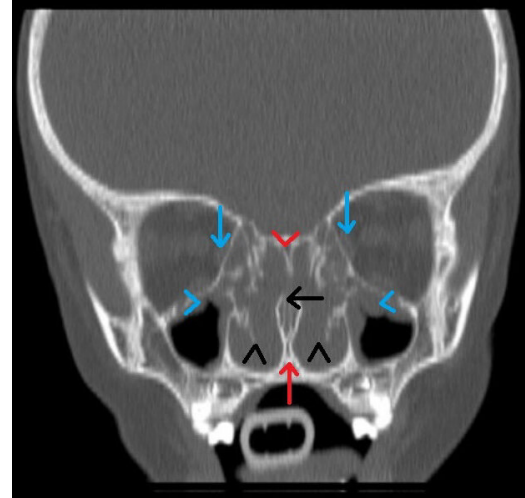

Figure 2 Radiologic appearance of nasal masses. CT landmark sinus without contrast in the coronal plane showing soft tissue densities encompassing the bilateral nasal cavities. There is soft tissue thickening of the bilateral maxillary sinuses. No bony erosion or intracranial continuity is seen. (Black arrowheads=soft tissue masses, black arrow=nasal septum, red arrow=maxillary crest, red arrowhead=perpendicular plate of the ethmoid, blue arrowheads=soft tissue thickening of the bilateral maxillary sinuses and blue arrows=medial rectus muscles.)

sinonasal inflammatory changes, the decision was made to proceed with staged surgical intervention that first involved both mucosal and submucosal reduction of the bilateral inferior turbinates, bilateral maxillary antrostomies, bilateral anterior ethmoidectomies, adenoidectomy and placement of silastic sheeting to prevent adhesion formation. In the second stage 1 week later, the silastic was removed, but persistent inflammatory changes were observed in the sphenoethmoidal recesses, so the decision was made to proceed with completion posterior ethmoidectomy and sphenoidotomy. One month postoperatively, his nasal airway appeared widely patent, and his mother reported significant improvement in nasal breathing.

The differential diagnosis of paediatric nasal masses is extensive and includes nasal dermoid cyst, glioma, encephalocele, nasolacrimal duct cyst, papilloma, chondroma, chordoma, meningioma, haemangioma, teratoma and reactive mucosal hypertrophy. ${ }^{1-3}$ More generally, paediatric nasal masses can be divided into congenital, inflammatory and neoplastic aetiologies. Occasionally, inferior turbinate hypertrophy can be so severe that it leads to reactive sinus disease, ${ }^{2-4}$ as was seen here. Nasal masses noted in the perinatal period are generally limited to the congenital type, but differential diagnosis broadens with increasing age and 
must include reactive and inflammatory lesions such as nasal polyps or mucosal hypertrophy. ${ }^{5}$ The diagnosis of nasal masses is made primarily through careful history and physical examination, with imaging indicated in cases where diagnosis is questionable or when there is concern for intraocular or intracranial connection. Overly aggressive biopsy should be approached with

\section{Patient's perspective}

Patient's mother: For years, I could not get my child to breathe through his nose no matter how hard I tried. He would cry to me constantly complaining that he could not breathe, and that made me feel bad as a parent. It was hard for the entire family to go through. I started to feel like he would never get better on his own, so I brought him to the doctors, who took great care of him from the start. It took three surgeries to get him better. That was also hard on him and on me as a parent, but they were able to fix his breathing. It was a lot for him to go through, but he is so much happier now, and that is all that a parent could ever ask for.

\section{Learning points}

- The differential diagnosis of nasal masses in the paediatric patient is extensive and any suspicious mass should be worked up thoroughly.

- Despite being one of the most common diagnoses otolaryngologists make, severe hypertrophy of the inferior turbinates can unusually present with visible nasal masses, as was seen here.

- Medical therapy with intranasal corticosteroids is considered first-line therapy, but in severe cases, surgery is required for complete resolution. caution, as it can precipitate severe haemorrhage in vascular lesions or could trigger a severe central nervous system infection in cases of encephalocele. ${ }^{1}$

Despite being an entity that many otolaryngologists diagnose several times daily, severe inferior turbinate hypertrophy can sometimes represent a diagnostic challenge. Although intranasal steroids and antihistamines are considered first-line therapy, surgical intervention has been shown to be successful in severe cases. ${ }^{4}$ Using modern mucosal-sparing techniques, such as radiofrequency ablation and submucosal reduction, otolaryngologists can expect improvements in their patients' outcomes even in the most extreme cases.

Contributors This manuscript is approved by all authors and has neither been previously reported nor been submitted for report in any other publication. NAR and MLS: drafting and editing of manuscript. SAD: Concept, guidance and review of manuscript.

Funding The authors have not declared a specific grant for this research from any funding agency in the public, commercial or not-for-profit sectors.

Competing interests None declared.

Patient consent for publication Obtained.

Provenance and peer review Not commissioned; externally peer reviewed.

ORCID iD

Nicholas Armando Rossi http://orcid.org/0000-0002-7105-2196

\section{REFERENCES}

1 Harley EH. Pediatric congenital nasal masses. Ear Nose Throat J 1991;70:28-32.

2 Rodriguez DP, Orscheln ES, Koch BL. Masses of the nose, nasal cavity, and nasopharynx in children. Radiographics 2017:37:1704-30.

3 Smith MM, Ishman SL. Pediatric nasal obstruction. Otolaryngol Clin North Am 2018:51:971-85.

4 Komshian SR, Cohen MB, Brook C, et al. Inferior turbinate hypertrophy: a review of the evolution of management in children. Am J Rhinol Allergy 2019;33:212-9.

5 Dupin $\mathrm{CL}$, LeJeune FE. Nasal masses in infants and children. South Med J 1978;71:124-8

6 Gupta A, Mercurio E, Bielamowicz S. Endoscopic inferior turbinate reduction: an outcomes analysis. Laryngoscope 2001;111:1957-9.

Copyright 2021 BMJ Publishing Group. All rights reserved. For permission to reuse any of this content visit https://www.bmi.com/company/products-services/rights-and-licensing/permissions/

BMJ Case Report Fellows may re-use this article for personal use and teaching without any further permission.

Become a Fellow of BMJ Case Reports today and you can:

- Submit as many cases as you like

Enjoy fast sympathetic peer review and rapid publication of accepted articles

- Access all the published articles

Re-use any of the published material for personal use and teaching without further permission

Customer Service

If you have any further queries about your subscription, please contact our customer services team on +44 (0) 2071111105 or via email at support@bmj.com.

Visit casereports.bmj.com for more articles like this and to become a Fellow 